\title{
DEVELOPMENT AND APPLICATION OF A METHOD \\ FOR QUALITY ASSESMENT OF PERISHABLE FOOD SUPPLIERS FROM A FOOD SERVICE
}

\section{DESARROLLO Y APLICACIÓN DE UNA METODOLOGÍA DE EVALUACIÓN DE LA CALIDAD DE PROVEEDORES DE ALIMENTOS PERECIBLES DE UNA UNIDAD DE ALIMENTACIÓN Y NUTRICIÓN}

\author{
Heliane Aparecida Barros de Oliveira (1), Monise Viana Abranches (2), \\ Ceres Mattos Della Lucia (1), Helena Maria Pinheiro Sant'Ana (1)
}

(1) Department of Nutrition and Health, Federal University of Viçosa, Brazil.

(2) Department of General Biology, Federal University of Viçosa, Brazil.

\begin{abstract}
Studies evaluating the quality of food providers and the guidelines for their better qualification are scarce in literature. A structured checklist was applied in the supplier establishments to evaluate: infrastructure, sanitaryhygiene control of foods and handlers, and conditions of transportation and receiving. The Supplier Quality Index was used to calculate the scores of vendors, and the score was assigned according to the fulfillment of the items presented on the checklist: "compliant", $\geq 75.0 \%$ compliance and "non compliant", $<75.0 \%$. The items "control of food hygiene and sanitary" and "infrastructure" showed the highest rate of compliance $(85.15 \%$, each), while the "sanitary-hygiene control of handlers" was that of most frequent non-compliance (80.0\%). The proposed methodology was efficient and may serve as a model to be employed for evaluation of supplier performance. Key words: supplier qualification; checklist; sanitary-hygiene quality; food safety; nutrition.
\end{abstract}

Este trabajo fue recibido el 13 de Abril de 2011 y aceptado para ser publicado el 15 de Mayo de 2011.

\section{INTRODUCTION}

Food Services (FS) are important sectors within the companies where they are established (5). In this segment, the quality of the raw material is essential for ensuring the supply of safe food, from both the health and nutritional point of views. Previous studies $(6,7)$ reveal that evaluation of the infrastructure of those providing foodstuff, the product and conditions of delivery are the principal critical control points in the food acquisition stage. Such assessments allow FS to provide adequate, safe and balanced food (5), these aspects being supported by definition of Food and Nutritional Safety.

Reports from the World Health Organization (WHO) and information on foodborne diseases in Brazil show that over $60 \%$ are food poisoning. This is due to improper handling practices, contaminated raw materials and the lack of hygiene throughout the production chain from the supply of raw materials to consumption (5).
To assist and ensure the quality and safety of food intended for human consumption, Good Manufacturing Practices (GMP) or Good Preparation Practices (GPP) have been established, a set of standards that should be used for products, processes, services and preparation. In Brazil, GMPs are legally governed by certain ordinances and resolutions, foremost among these are Ordinance No 1.428/1993, Ordinance No 326/1997, Resolution RDC No 275/2002 and Resolution RDC No 216/2004 (9 - 12).

The assessment of GMP in food production and commercialization establishments, through appropriate use of questionnaires, is cited to support qualification and selection of suppliers based on a fiscal sanitary inspection by the establishment in order to comply with these criteria, or as the basis for the deployment of the Hazard Analysis and Critical Control Points system (HACCP) (5). Thus, the relationship between purchasers and suppliers allows that efforts are combined to create 
and maintain a network of services in order to achieve the desired improvements of both parties $(2,3)$.

In case of suppliers, the partnership with companies allows to increase the quality of the products supplied (2). Improvement initiatives should revolve around the critical points, i.e., those processes deemed essential for the company to achieve its goals. Moreover, it is observed that the problems of one supplier may be generalized to others of the same productive chain, which may facilitate corrections by means of simple measurements (4).Despite the importance of studies on the analysis of supplier quality and food safety in the food service segment, it was observed that there is a gap in this field of research.

Thus, when considering that the evaluation of suppliers to the food service area is essential to minimize health risks and meet high quality standards, the objective of the present study was to develop and implement a method for assessing the quality of perishable food suppliers to an industrial FS.

\section{MATERIALS AND METHODS}

The evaluation was guided by the concept of safe food, with the objective of obtaining data that could contribute to improve the quality of services provided by suppliers of perishable foods, in order to guarantee their quality. A non-experimental survey was conducted, based on the observation, recording and analysis of variables without their manipulation (13). This was a quali-quantitative study whose focus was the quality of 12 suppliers of meat, horticultural, bakery and dairy products to a FS belonging to a furniture industry, located in the city of Ubá, Minas Gerais, Brazil, which serves approximately 2,500 meals per day.

Although suppliers do not provide the same perishable products to the FS, we chose to evaluate all suppliers that attended the company. This is because the foods provided have in common their short shelf life, given the inherent characteristics of their matrices (eg, high water activity, high nutrient content, etc.).

As already established, if these foods are handled and stored without the proper microbiological and nutritional quality and safety criteria, they can cause serious damage to health of those who consume them. Moreover, in Brazil, all food manufacturing establishments must meet specific legislation (Resolution RDC No. 275/2002 of the Brazilian National Agency for Sanitary Surveillance) which provides the Technical Regulation of Standard Operating Procedures to be applied in these establishments and the Checklist of Good Manufacturing Practices (11). Thus, suppliers were evaluated according to their infrastructure, sanitary-hygienic control of food and handlers, transport and receiving of foods. The evaluation was performed by applying a checklist, developed in accordance with Resolution RDC No. 275/2002 (11). The checklist was divided into four groups: identification, assessment, recording observations and scoring of the establishment (table 1). Conditions of infrastructure, sanitation, processing, transport conditions and meeting of delivery deadlines was observed for suppliers of breads, meats, fruits and vegetables, juices and dairy products, as well as the quality of the foodstuffs supplied at each delivery point, the quantity, the packaging integrity and, when necessary, the temperature of the product.

\section{TABLE 1}

\section{Evaluation of suppliers to FS with regards to infrastructure, hygiene-sanitary control of foods and handlers, shipping and receiving.}

Elements and characteristics observed

\section{Supplier compliance}

Yes

n
No

n $\%$

\section{Infrastructure}

Cleanliness and organization of dependencies, with no trash,

debris and regions of insalubrity

$\begin{array}{cccc}11 & 91.6 & 1 & 8.4 \\ 12 & 100.0 & 0 & 0.0 \\ 9 & 90.0 & 1 & 10.0 \\ 11 & 91.6 & 1 & 8.4\end{array}$

Walls of light color, smooth and washable

Lack of housing or dormitory on the premises of the establishment*

Floor coverings in good condition and clean.

11 
Wall cladding and roof in good condition, clean and free of mold and mildew

$\begin{array}{cccc}9 & 75.0 & 3 & 25.0 \\ 9 & 75.0 & 3 & 25.0 \\ 11 & 91.6 & 1 & 8.4 \\ & & & \\ 10 & 83.3 & 2 & 16.7 \\ 6 & 60.0 & 4 & 40.0 \\ & & & \\ 10 & 83.3 & 2 & 16.7 \\ 10 & 83.3 & 2 & 16.7 \\ 8 & 88.9 & 1 & 11.1 \\ 8 & 66.7 & 4 & 33.3 \\ 12 & 100.0 & 0 & 0.0\end{array}$

Screen doors and windows, cleaned and conserved

Adequate lighting to allow visibility in all locations

Natural and/or artificial ventilation facilitating conservation of the roofs

(free of moisture and mold)

Presence of specific sinks for food handlers to wash hands in the handling areas*

Separate toilet facilities for each sex, with their sink in good condition,

toilet paper, water, liquid soap, paper towels and trash cans

Water reservoirs accessible, clean and covered

Exhaustion equipment in good condition and operation *

Suitable location for waste storage

General organization

$\begin{array}{cccc}12 & 100.0 & 0 & 0.0 \\ 11 & 91.6 & 1 & 8.4 \\ 9 & 90.0 & 1 & 10.0 \\ 7 & 100.0 & 0 & 0.0 \\ 10 & 100.0 & 0 & 0.0 \\ 11 & 91.6 & 1 & 8.4 \\ 5 & 45.5 & 6 & 54.5\end{array}$

\section{Food Hygiene and Sanitary Control}

Appropriate fiscal data

Absence of domestic animals, flies, insects and rodents and their remnants

Foods packaged and stored properly, in proper temperature,

protected from dust, insects, rodents *

Thawing of food done correctly *

Packaging and containers stored correctly *

Correct disposal of food scraps

Use of sanitizers for food products and facilities approved by the Ministry of Health*

\section{Hygiene and sanitary control of manipulators}

Use disposable gloves to handle food ready *

Use a full working uniform, light colored, well conserved and clean and closed shoes

Hands clean, nails trimmed and clean, no jewelry on the fingers,

neck, ears and/or wrists *

Satisfactory body cleanliness, hair covered and no beards and mustaches*

$66.7 \quad 4$

Ergonomic aspects (tasks performed by employees and work environment

should not act as risk factors to health of employees)

\section{Transportation and receiving of the products}

Adequate transport (transport vehicle hygiene, organization of the goods

transported to the product suitable temperature, general condition of vehicle)

Good quality product delivery

Quantity delivered in accordance with the request made

Professionalism of delivery, personal hygiene, conditions of the uniform, identification of the company (use ID badge) and troubleshooting capabilities when there are problems with the product or during delivery.

* The number of suppliers was different from 12, since some suppliers were not applicable when considering the foods they provide. 
Meeting of delivery deadlines and the rate of rejection were scored as demerits according to the number of delays and rejections during the period of study. The evaluation consisted of "yes", "no" and "not applicable", with one point for each "yes", zero for each "no" and when "not applicable", the score was canceled, giving a total of 30 points which corresponded to $100 \%$ of the evaluated items. The checklist was applied by qualified and trained people during technical visits to suppliers and when receiving raw materials at the FS.

The criteria for evaluation of suppliers were based on the equation of the Supplier Quality Index (SQI) according to Coquemala (2006) (14), given by:

$$
\mathrm{SQI}(\%)=[(\mathrm{IQSx} 0.2)+(\mathrm{DQIx} 0.3)+(\mathrm{RQIx} 0,5)] \times 100
$$

\section{Where:}

Supplier Quality Index (SQI): scores in the checklist; Delivery Quality Index (DQI): compliance with the deadline previously established at the time of acquisition of products;

Receiving Quality Index (RQI): number of product returns that were outside the standard of quality required by the FS.

This calculation is considered the basis for deve- lopment of a list of qualified suppliers. The SQI takes into account the Total Quality practiced by the supplier in terms of meeting the requirements of Sanitary Surveillance (GMP) and verifies the status of Quality System.

The minimum percentage accepted by the industry quality sector and considered in this study for classifying the supplier as "compliant" was $75 \%$. A supplier who did not meet this target was classified as "non compliant" (figure 1). After calculation and analysis of the quality of the FS suppliers involved in this study, a meeting was scheduled with each supplier in order to describe the situation observed in their establishment, emphasizing the criteria to be improved in the stages of production and supply of foodstuffs.

\section{RESULTS AND DISCUSSION}

In order to facilitate analysis and discussion of obtained results, the contents of the checklist was grouped in topics and suppliers were presented according to the type of product provided.

Some of the features observed with regards to the infrastructure of suppliers, such as the presence of a sink for washing hands and a suitable location for waste storage were in disagreement with recommendations in $40.0 \%$ and $33.3 \%$, respectively (table 1). Similarly, Bramorski

\section{FIGURE 1}

Stages of experimental development of the research.

- Supplier Quality Index System: the supplier follows the guidelines laid down by Resolution No. 275/2002? (The checklist was used for this evaluation). This item accounted for $20 \%$ of Supplier Quality Index.

- Delivery Quality Index: The supplier meets the delivery time of products? This item accounted for $30 \%$ of Supplier Quality Index.

- Receiving Quality Index: products are delivered within the quality standards required by the FS? This item accounted for $50 \%$ of Supplier Quality Index.

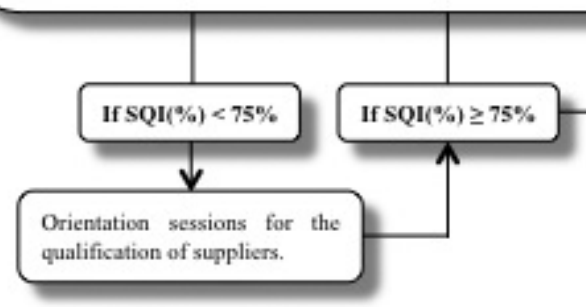


et al. (2004) (15) and Deschamps et al. (2003) (16) found no lavatories for the exclusive use of handler in bakeries and pastry shops in the city of Joinville, SC, and FS in the city of Blumenau, SC, respectively, as well as the absence of liquid soap and disposable towel for proper hand cleaning and sanitizing procedures. Castro et al. (2006) (17), when evaluating the sanitary conditions of self-service restaurants, found that $77.8 \%$ of establishments had no lavatories in the production area and only $11.1 \%$ had a lavatory with toiletries suitable for proper hand washing. Although this study found the percentage of mismatches lower than that observed by Castro et al. (2006) (17), it is important to note that, in absolute terms, the inadequacies deserve special attention from suppliers who should seek to minimize the risk of food contamination when changing of activity.

It is not always possible to modify the locations where food is handled to meet all requirements of legislation, but these can be adapted, resulting in the development of an excellent working environment without risk of food contamination $(11,18)$. The construction of food handing and supply establishments must provide features that ensure hygiene and efficient use of good practice $(19,14,20)$.

Thus, with regards to the storage of garbage, this study found a high percentage of non-compliance $(33.3 \%)$ since there were no suitable areas for storage (table 1). This result is similar to that found by Cardoso and Souza Santos (2005) (6) in a study conducted at the FS on the campus of the Federal University of Bahia, which revealed that in $50 \%$ of the units studied, storage of garbage in food handling areas was done in buckets with plastic bags, however, more than half of the containers had no lids, favoring the proliferation of insects. In a work performed by Damasceno et al. (2002) (21) self-service restaurants surrounding the Federal University of Pernambuco showed that the flow of garbage was not different from that of food, which possibly favored cross-contamination. This observation was also made in this study, where in all establishments evaluated the garbage was removed at the same place where the foodstuffs were received.

The item "bright tone, smooth and washable walls" showed maximum suitability similar to that reported by Cardoso and Souza Santos (2005) (6), who found that $70 \%$ of the units studied had smooth walls, $80 \%$ had walls for easy cleaning and $90 \%$ of establishments light colored walls. In contrast, Schons et al. (2006) (22) found that $41.2 \%$ of the 17 commercial establishments responsible for the sale of fresh vegetables in the city of Pelotas (Rio Grande do Sul) did not meet the legislation in relation to the physical aspects related to access, types of wall, floor, ceiling doors, windows and lighting. Contrary to observations in this study, Stelmaszczyk et al. (2006) (23) found in the establishments of fish suppliers that walls, partitions and floors were in poor condition, with broken, cracked and peeling paint. The item that met the recommended criteria was "ceiling lining constructed of washable materials with smooth surfaces and light colors". The results showed that a significant number of businesses analyzed in this study presented limitations with regards to basic aspects of the building, possibly compromising the quality and durability of its products.

Hygiene of working facilities, preparation rooms, sinks and desks, cold rooms, refrigerators and pantries is important to prevent contamination of food (Germano et al., 1999) (24), where sanitary-hygienic control of the environment through the use of quality products and sanitizers approved by the Ministry of Health are factors that determine safety of the foods provided. In this study, $54.5 \%$ of suppliers did not use sanitizer products approved by the Ministry of Health, which differs from results obtained by Cardoso and Souza Santos (2005) (6) in which all materials used in the canteens studied were registered by department.

It was noted that for the item "appropriate fiscal data", $100 \%$ of the supplying establishments were in compliance with current regulation. A different result was found by Pereira (2006) (25) in which different FS, although $34 \%$ of the services examined were aware of the need to have documents and records proving the application of legislation, none fulfilled the requirements. It is emphasized that the regulation of processes that make up the food supply chain is a way of legitimizing the duties of those who are willing to provide safe food to their customers.

With regards to the thawing process, it is known that the safe conduct of this practice may involve distinct procedures such as use of cold rooms or refrigerators at temperatures near $4^{\circ} \mathrm{C}$; using convection ovens or microwaves; and immersion in water with temperatures below $21^{\circ} \mathrm{C}$ for four hours, with subsequent maintenance at room temperature in a location free of contamination, until the surface reaches $3^{\circ} \mathrm{C}$, after which the product is placed in the refrigerator to finish thawing (Silva, 1999) (26). In general, adequate thawing is not conducive to microbial growth, but when thawed foods remain at room temperature for several hours or in refrigerator for several days there may be the multiplication of psichrophilic and mesophilic pathogenic bacteria. When meeting some conditions for safe thawing of foods, their unique features do not change. Parameters of temperature, time, environmental conditions and protection of the food must be respected to prevent loss of sensory 
characteristics during the thawing process (27).

In our work the thawing process performed by the suppliers presented $100 \%$ compliance, although other studies did not obtain satisfactory results. Cardoso and Souza Santos (2005) (6) found that in $65 \%$ of canteens the thawing of meat, poultry and fish was conducted at room temperature and only $20 \%$ of establishments thawed these products in the refrigerator. Pereira (2006) (25) noted that despite the four establishments studied being aware of the ideal conditions of thawing of frozen products, only one had implemented the correct technique.

According to Valente and Passos (2004) (28), storage of food next to toxic substances or strong odors is considered highly inadequate. The packaging of cleaning products in a ventilated location and protected by barriers to prevent release of odors in the areas of food handling reduces contamination of food products by volatile compounds. In the present study we observed that $100 \%$ of suppliers maintained both cleaning materials and perishable and little perishable foods in appropriate locations, different from that observed by Castro et al. (2006) (17) who found that only 2 of 9 establishments surveyed had their products stored in proper locations.

The personal hygiene of vendors, as well as food handlers, direct or indirect, involved in providing the raw material is of fundamental importance since this represents the main vehicle for microbial contamination. For this practice to be complete, some measures must be taken, such as using a proper uniform (light-colored clothes without buttons, closed shoes, gloves, masks and apron, if necessary) and presenting no disease that compromises the handling of food. The injuries to the hands must be carefully observed because wounds may transfer the microorganisms Staphylococcus sp. or Streptococcus sp. (29).

With regard to this issue was the item "satisfactory body cleanliness, hair covered and absence of mustaches and beards" showed a percentage of compliance equal to $80.0 \%$. This result is important, since one of the main causes of diseases of microbial origin is resultant of the mishandling of food. The good health of the handler and appropriate personal hygiene habits will lessen the risk of food contamination caused by pathogenic microorganisms that endanger the health of individuals, ensuring production of safe and secure foods $(29,30)$.

According to Almeida et al. (1995) (31), the first requirement of personal hygiene is that the food handlers wash their hands thoroughly with soap and apply sanitizing solution at least before starting work and after handling food, at each change of function and after using the lavatory. Commonly, hygiene is generally limited to the care of hands, but the term should be much more comprehensive, since any manipulation performed by an individual results in a risk factor to food safety (32).

For the other items that concern the hygienic and sanitary control of manipulators, the encountered compliance was less than $75.0 \%$, which demonstrates great concern about the need for guidance and access to hygiene products that guarantee a lower risk of contamination. This finding emphasized the need to develop workplace guidelines for the contracted service company, being that this is an important issue for all providers linked with the customer since a significant portion did not meet regulatory requirements.

The transport and receiving of foods are the first steps of sanitary-hygiene control and the quality control issues of products received must be understood (33). As emphasized by Kubitza and Ono (2006) (34) in his analysis of fish, customers should pay attention to product presentation (packaging and overall look), conditions of storage and transportation, delivery, delivery volumes, prices and conditions of agreed payment. Considering these criteria, it was found in the present study that for the group "transportation and receiving of the foods", the parameter "amount delivered in accordance with the request made" received a high percentage of compliance $(91.6 \%)$. The items "suitable transportation" and "quality of the product on delivery" were also found within the appropriate range of compliance (>75.0\%). A high proportion of adequate delivery was also found by Cardoso and Souza Santos (2005) (6) in which $100 \%$ of those responsible for the facilities analyzed reported validity of the products delivered, $85 \%$ observed sensory aspects of the product and 95\% were concerned with evaluating the packaging conditions. In the present study, food suppliers whose requiring controlled temperature transportation showed full compliance, which can be considered an important factor in ensuring the quality of the food purchased.

In addition to evaluating the shipper with regards to the conditions of delivery and how the product is handled, the attitude of the buyer must also be observed. These factors affect the quality of product provided, and reflect the image of the supplier in the market. In the present study, the item "professionalism of the delivery" returned $33.3 \%$ "non compliance", which negatively affects the image of the supplier company and demonstrates the need for training and orientation. Professionalism of the company should be evaluated even at the time of delivery, including the timeliness of delivery and presentation of the vehicle, such as cleanliness, refrigeration system and periodic insect and rodent control are factors of great importance for 
preserving food quality. A study conducted by Schneider (2006) (5), which examined the supply of fruits and vegetables, showed that the aspects that most influence the signing of contracts with suppliers were: 1 ) hygiene of the product, truck and boxes, 2) willingness to meet unplanned requests, 3) maintenance of quality standard and 4) confidence in the supplier.

Periodic audits to suppliers should be conducted by food service units and other food producing establishments, in order to identify the situation-problem and propose improvements. In this sense, the SQI was calculated for each group of perishable commodities supplied.

With respect to suppliers of meat, it was found that the degree of compliance was less than $85 \%$ when evaluated by the SQI (figure 2). Suppliers C and E, despite conforming, still require further qualification because hygiene and sanitary control of these raw materials (protein foods such as meat, milk and dairy products and eggs) are most important given their high perishability (26).

The SQI percentage was greater than or equal to $86 \%$ for suppliers of bakery products (figure 3), and the suppliers B and C reached indices greater than $90 \%$. Despite the need or adjustments, these results can be considered satisfactory.

Vegetable supply chains are currently facing the challenge of aligning demand and supply of products efficiently. On the demand side, demanding clients are interested in high quality products. On the supply side is the difficulty in ensuring the right product at the right time and right place (35). In this context, it was observed that the two suppliers of fresh product evaluated showed an SQI above 82\%. Differently, Schneider (2006) (5) when assessing the supply of fresh produce for hospital FS, verified that essential factors were not in compliance, including the controlled use of pesticides, sanitary conditions, and the origin and transport conditions.

For suppliers of beverages (including juices, milk and dairy products such as yogurt) the SQI values were the highest (nearly $100 \%$ compliance), which reflects the supply of high quality foods in terms of both hygiene and nutrition, as well as timely delivery.

Studies with the objective of evaluating the quality of food supplies are scarce in literature. However, some authors support the idea of developing methodologies to measure the performance of suppliers. Starbird (2007) (36) states that the ability to separate vendors concerned with providing safe food from those who do not have this responsibility depends on the use of reliable methodologies. Thus, the present study can be used as a model to be used in future works, as well as in daily practices of companies in the food sector.

FIGURE 2

Quality index of meat suppliers.

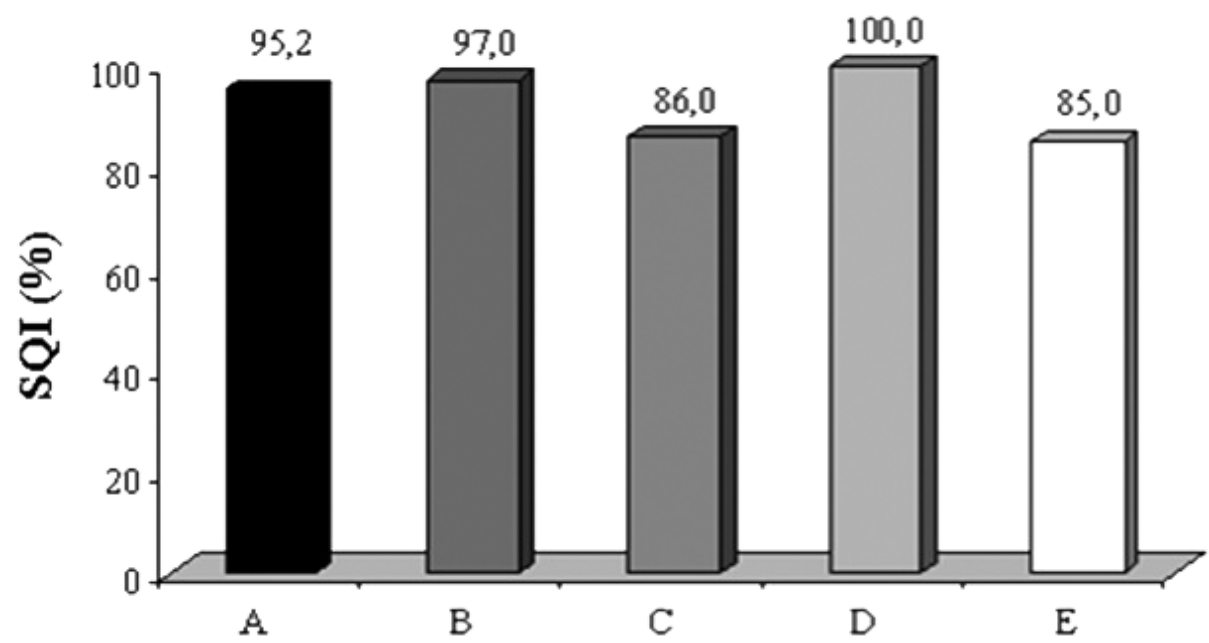

Meat supplier 
Besides the regular inspection of the vendor establishment, it is necessary to prevent food-borne diseases by educating and training operators who directly or indirectly manipulate foods for consumption since it is considered essential to incorporate practices aimed at quality control and food safety. The education level of workers, qualification resulting from professionalization courses, training programs and experience in the area of actuation are among the factors that contribute to food security throughout the entire chain of food production (37).

The partnership between buyer and supplier can serve as a tool for improving the services provided by suppliers, which adds value to the product offered and guarantees the delivery of quality products, this being the initial point for safe food production by the FS. Orientation sessions and a partnership between the FS of the present study and their suppliers, although not systematic, were already effectuated 15 years ago. Thus, such involvement has certainly contributed to the high rates of compliance obtained by the suppliers. However, according to Serna-Cock et al. (2009) (38), the responsibility of providing healthy and safe food involves all members of the production chain, from suppliers to distributors and final consumers. These authors developed a good practice plan hygiene of food and the working environment, as well as training of handlers for a food distribution establishment with the intent of reducing the risk of foodborne diseases that most affect children and the elderly. This strategy led to an increase of $70 \%$ in the implementation of good practices, which represents a solid basis for ensuring the acquisition of safe food and reducing the risk of foodborne illnesses. In accordance with the benefits revealed in this work for the company/supplier partnership, Rêgo et al. (1997) (39), when evaluating industrial FS, observed that the training contributed to the improvement of sanitary conditions of the staff and environment. The results also indicated the need for continuing education programs for the manipulators, with the intention of involving them in changes proposed by training. Continued education involves the inclusion of individuals in teaching and learning, targeted primarily to professional activities, aimed at recycling and amplification of the content.

Neumann (2002) (40) noted that companies are seeking new organizational models that offer better conditions of external competitiveness. In this sense, it can be said that the partnership developed between the company and suppliers is a key competitive tool in the global market and can be achieved through programs that encourage this exchange of benefits. The author argues that involvement and partnership with suppliers lead to the delivery of high quality foods at the agreed time. However attention should be paid to the degree of

\section{FIGURE 3}

Quality index of bakery products suppliers.

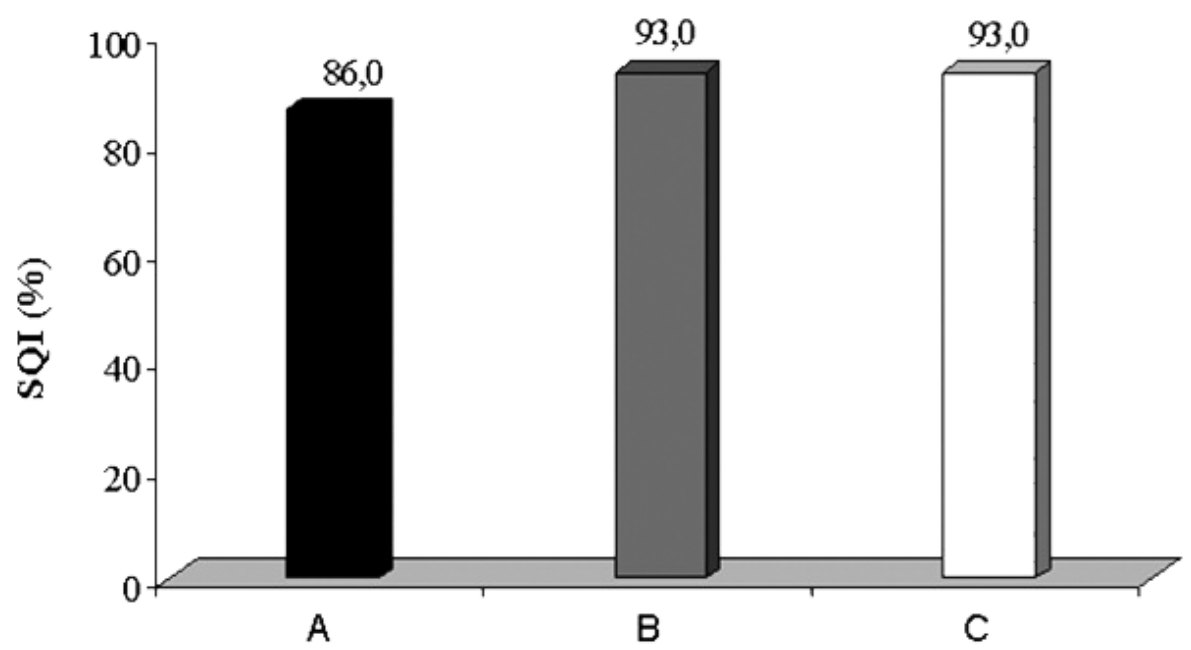

Bakery products suppliers 
detail provided to small suppliers because it is necessary to contributed to development of the specifications to be met.

Orientation sessions for the qualification of suppliers is advantageous because it allows for presentation of matters related to food security and nutrition, and contribute to their satisfactory performance, leading to the delivery of high quality foods on time. Therefore, to maintain the high quality of meals served it is essential that the FS assumes a solid partnership with those who supply their raw materials.

In the present study, as an alternative form making the suppliers' aware to the importance of adapting their products and services to the requirements delegated by the FS, after analysis of their capacity, periodic training programs began to be employed in this segment in order to inform individuals of adequate production, transport, storage and distribution of perishable foodstuffs. The training also aimed to educate vendors about the notions of hygiene, proper techniques for food handling and practices that ensure the safety of the meals offered to customers in order to prevent foodborne diseases by means of the working partnership.

Other activities proposed were also proposed including: visits to other suppliers of similar products and subsequent discussion on what was observed in regards to the food supply chain, elaboration and distribution of a seal of quality for suppliers to be offered by the FNS, with the objective demonstrate the growing improvement in quality of products supplied to the food service industry. After adoption of training and conducting other activities on a regular basis, the suppliers were evaluated twice a year with the goal of achieving $100 \%$ compliance of all items analyzed.

As reported by the corroboration FS of the present study, the following were noted: increase in flexibility, technical assistance of the supplier, reduction in response time, reduction of costs and increase quality of the foods received. The suppliers observed improvements in planning of the delivery, guaranteed demand and regular technical service by the FS.

\section{CONCLUSIONS}

The proposed evaluation methodology showed to be efficient and practical, and may serve as a reference to be used in other FS.

The FS partnership with suppliers, including periodic training programs and preparation and distribution of a seal of quality contributed to their satisfactory performance.

The impact resulting from regular assessment of the quality of suppliers and the new relationship between suppliers and the FS is the focus of many new studies, whether it be for economic reasons or for improvement of product quality by both parties.

\section{RESUMEN}

Pocos estudios evalúan la calidad de los proveedores de materia prima y los guían para que cumplan mejor los requisitos. En este trabajo se utilizó una lista de verificación en los establecimientos de los proveedores para evaluar: infraestructura, control sanitario de los alimentos y manipuladores, así como las condiciones de transporte y recepción de la material prima. Se utilizó el Índice de Calidad del Proveedor para calcular las puntuaciones, y la clasificación fue asignada de acuerdo con el cumplimiento de los ítems que figuran en la lista de verificación: "conforme" $\geq 75,0 \%$ y "no conforme" $<75,0 \%$ de cumplimiento. El ítem "control higiénico de los manipuladores" tuvo la mayor frecuencia de incumplimiento (80\%), mientras que los ítens "control higiénico del alimento" y "infraestructura" mostraron el más alto índice de cumplimiento $(85,15 \%$, cada). La metodología propuesta fue eficiente, y puede servir como modelo a ser utilizado para la evaluación de los proveedores.

Palabras clave: calificación de los proveedores; lista de verificación; calidad higiénica; seguridad alimentaria; nutrición.

Corresponding author:

Helena Maria Pinheiro Sant'Ana

Department of Nutrition and Health

Federal University of Viçosa

Av. Purdue, s/n, Campus Universitário

CEP: 36.571-000. Viçosa, MG, Brazil.

Phone: +55 3138993731

Fax: +55 3138992545

E-mail: helena.santana@ufv.br.

\section{REFERENCES}

1. Crawford KM, Cox J F. Addressing manufacturing problems through the implementation of Just-intime. P\&IM 1991; 32(1): 33 -6.

2. Silva JES. As Relações entre Fornecedores e as Montadoras automobilísticas na década de 90 (1997). São Paulo: Pontifícia Universidade Católica de São Paulo, Brazil, 1997.

3. Kaibara MM. A Evolução do Relacionamento entre Clientes e Fornecedores: Um Estudo de suas Principais Características e Contribuições para a Implantação da Filosofia JIT (1998). Florianópolis: Universidade Federal de Santa Catarina, Brazil, 1998. 
4. Vermeulen W, Edgeman R. Continuous Quality Improvement Strategies in the Retail Banking Industry of South Africa. Quality Engineering, 2000; 13(2): 245-50.

5. Schneider AP. Fornecimento de hortifrutigranjeiros para unidades de alimentação e nutrição hospitalares. Ciênc Tecnol Alim 2006; 26(2): 253-8.

6. Cardoso RCV, Souza EV, Santos PQ. Unidades de alimentação e nutrição nos campi da Universidade Federal da Bahia: um estudo sob a perspectiva do alimento seguro. Rev Nutr 2005; 18(5): 669-80.

7. Nonino-Borges, $\mathrm{CB}$ et al. Desperdício de alimentos intra-hospitalar. Rev Nutr 2006; 19(3): 349-56.

8. Belik W. Perspectivas para segurança alimentar e nutricional no Brasil. Saúde Soc 2003; 12(1): 12-20.

9. Brasil. Ministério da Saúde. Secretaria de Vigilância Sanitária. Portaria $\mathrm{n}^{\circ} 1.428$, de 26 de novembro de 1993. Regulamentos Técnicos sobre Inspeção Sanitária, Boas Práticas de Produção/Prestação de Serviços e Padrão de Identidade e Qualidade na Área de Alimentos. Diário Oficial da União, Brasília, 2 dez. 1993.

10. Brasil. Ministério da Saúde. Portaria n ${ }^{\circ} 326$, de julho de 1997. Regulamento técnico sobre as condições higiênico-sanitárias e de boas práticas de fabricação para estabelecimentos produtores/industrializadores de Alimentos. Diário Oficial da União, Brasília, 1 ago. 1997, Seção I, p.16560-3.

11. Brasil. Ministério da Saúde. Resolução - $R D C n^{\circ} 275$ de 21 de outubro de 2002. Regulamento técnico de procedimentos operacionais padronizados aplicados aos estabelecimentos produtores/industrializadores de alimentos e a lista de verificação das boas práticas de fabricação em estabelecimentos produtores/ industrializadores de alimentos. Diário Oficial da União, Brasília, 06 nov. 2002.

12. Brasil. Ministério da Saúde. Resolução - RDC n ${ }^{\circ}$ 216, de 15 de setembro de 2004. Regulamento Técnico de Boas Práticas para Serviços de Alimentação. Diário Oficial da União, Brasília, 15 set. 2004.

13. Martins GA apud Berto MA. Modelo de mensuração e decisão dos principais eventos econômicos de uma empresa do setor sucroalcooleiro: uma abordagem de gestão econômica (2001). São Paulo: Universidade de São Paulo, Brazil, 2001.

14. Coquemala MA. Avaliação de fornecedor de componentes. Boas práticas de fabricação / HACCP / Tecnologia de alimentos e matérias-primas / Novas tecnologias, Belo Horizonte, 2006.

15. Bramorski A, Ferreira A, Kleis G, Dominoni, M. Perfil higiênicosanitário de panificadoras e confeitarias do município de Joinville, SC. Hig Aliment
2004; 18(123): 37-41.

16. Deschamps C, Freygang J, Bramorski A, Tommasi D. Avaliação higiênico-sanitária de cozinhas industriais instaladas no município de Blumenau, SC. Hig Aliment 2003; 17(112): 12-5.

17. 17. Castro FT, Tabai KC, Barbosa CG, Dorna NS. Restaurantes self-services: situação higiênicosanitária dos shoppings do município do Rio de Janeiro. Rev Univ Rural 2006; 26(2): 1-6.

18. Serviço Social do Comércio (SESC) Higiene e Apresentação Pessoal dos Manipuladores de Alimentos. São Paulo: SESC, 2004.

19. Talamini E, Pedrozo EA, Silva AL. Gestão da cadeia de suprimentos e a segurança do alimento: uma pesquisa exploratória na cadeia exportadora de carne suína. Gestão Produção 2005; 12(1): 107-20.

20. São José JFB, Pinheiro-Sant'ana HM. Assessment of good handling practices in a school food service. Nutrire 2008; 33(3): 123-38.

21. Damasceno KSFSC, Alves MA, Freire IMG, Tôrres GF, Ambrósio CLB, Guerra NB. Condições higiênico-sanitárias de "self-services" do entorno da UFPE e das saladas cruas por elas servidas. Hig Aliment 2002; 16(102/103): 74-8.

22. Schons PF, Mendonça SX, Klug CM, Barbosa EG, Rodrigues RS, Machado MRG. Análise das condições sanitárias de estabelecimentos comerciais de hortaliças. XI Simpósio de Iniciação Científica da Universidade Federal de Pelotas. http://www. ufpel.edu.br/xiicic/relatorios/conteudo_CA.html (acessed Feb 25, 2008).

23. Stelmaszczyk S, Barbosa EG, Rodrigues RS, Machado MRG. Aspectos físicos, higiênicos e sanitários de estabelecimentos comerciais de pescado. XII Congresso de Iniciação_Científica_da_Universidade Federal de Pelotas http.//www ufpel.edu. br/xiicic/relatorios/conteudo_CA.htm. (acessed Feb 25, 2008).

24. Germano PM L, Germano MIS, Oliveira CAF. Vigilância Sanitária de Alimentos, Parte I. São Paulo, FSP/USP, 1999.

25. Pereira CHC. Avaliação das Unidades de Alimentação e Nutrição da cidade de Franca visando a Promoção da Saúde (2006). Franca Universidade de Franca, Franca, São Paulo, Brazil, 2006.

26. Silva JRE. A. Manual de controle higiênico-sanitário em alimentos. São Paulo: Varela; 1999.

27. Piragine KO. Aspectos higiênicos e sanitários do preparo da merenda escolar na rede estadual de ensino de Curitiba (2005). Curitiba: Universidade Federal do Paraná, Paraná, Brazil, 2005.

28. Valente D, Passos ADC. Avaliação higiênico- 
sanitária e físico-estrutural dos supermercados. Rev Bras Epidemiol 2004; 7(1): 80-87.

29. Corrêa MS. As Práticas e Concepção de Higiene Pessoal - Determinantes do Treinamento de Manipuladores de Alimento de um Restaurante Industrial 2004. http://www.enut.ufop.br/nutline/artigos/ artigo03/artigo03.html (acessed Mar 03, 2008).

30. Silva J, Capuano DM, Takayanagui OM, Giacometti Júnior E. Enteroparasitoses e onicomicoses em manipuladores de alimentos do município de Ribeirão Preto, SP, Brasil. Rev Bras Epidemiol, 2005, 8(4): 385-92.

31. Almeida RCCA, Kuaye AY, Serrano AM, Almeida PF. Avaliação e controle da qualidade microbiológica de mãos de manipuladores de alimentos. Rev Saúde Pública 1995; 29(4): 290-4.

32. Riedel G. Controle sanitário. São Paulo: Atheneu, 1992.

33. Teixeira SMFG, Oliveira ZMC, Rego JC, Biscontini TMB. Administração aplicada a unidades de alimentação e nutrição. São Paulo: Atheneu; 1990.

34. Kubitza F, Ono EA. Percepções Sobre a Qualidade dos Produtos de Pescado. Revista Panorama da Aqüicultura. http://www.cca.ufc.br/ Percep\%E7\%F5es\%20Sobre\%20a\%20Quali- dade $\% 20$ dos $\% 20$ Produtos $\% 20$ de $\% 20$ Pescado. html.(acessed Mar 27, 2007).

35. Lourenzani AEBS, Silva AL. Um estudo da competitividade dos diferentes canais de distribuição de hortaliças. Gestão Produção, 2004; 11(3): 385-98.

36. Starbird SA, Amanor-Boadu V. Contract Selectivity, Food Safety, and Traceability. J Agricul Food Indust Organization 2007; 5(1) Article 2. http:// www.bepress.com/jafio/vol5/iss1/art2 (acessed Oct 20, 2010).

37. Cavalli SB, Salay E. Gestão de pessoas em unidades produtoras de refeições comerciais e a segurança alimentar. Rev Nutr 2007; 20(6): 657-67.

38. Serna-Cock L, Correa-Gomez MDC, Ayala-Aponte AA. Plan de saneamiento para una distribuidora de alimentos que atiende a niños y adultos mayores. Rev Salud Pública 2009; 11(5): 811-8.

39. Rêgo JC, Guerra NB, Pires EF. Influência do treinamento no controle higiênico-sanitário de unidades de alimentação e nutrição. Rev Nutr 1997; 10(1): 50-62.

40. Neumann CSR. Desenvolvimento de Fornecedores: Um Estudo de Caso no Setor de Máquinas Agrícolas. Porto Alegre: Universidade Federal do Rio Grande do Sul, 2002. 